\title{
COOPERATION BETWEEN THE EUROPEAN UNION AND EUROPEAN MINI-STATES - POSSIBLE SCENARIOS FOR FUTURE CLOSER AND ENHANCED INTEGRATION WITH THE EUROPEAN UNION
}

\author{
ADRIANA KALICKA-MIKOLAJCZYK*
}

\section{INTRODUCTION}

Within Europe, there are a number of small, independent, internationally recognised states which are the European Union's neighbours; however, they are not members of this organisation: the Principality of Andorra, the Republic of San Marino, the Principality of Monaco, the Principality of Liechtenstein and the Vatican City State ${ }^{1}$. Because of their small territorial areas and small populations they are collectively known as "mini or micro-states". Each of them conducts diplomatic relations with the European Union (EU) and their diplomatic missions are accredited to the EU at Ambassador level. The EU and San Marino established diplomatic relations in 1983 and in March 2016 the EU accredited its first Ambassador in San Marino. In cases of Andorra and Monaco, the EU is represented by one of its member States. During the last decade, all Mini-States have gradually developed their contacts and cooperation with the EU. Although each has developed quite separate relations with the EU, these relationships have developed along similar lines ${ }^{2}$. For example, all Mini-States, with the exception of Andorra, have entered into monetary agreements with the EU. In most cases, formal relations with the EU began with the signing of customs and cooperation agreements, and more recently most of them have entered into agreements with the EU on the taxation of the savings income of EU residents. However, they have no participatory rights in the EU's decision processes, but they constantly implement EU legislation in selected areas.

DOI: $10.1515 /$ wrlae-2018-0024

* Assistant Professor at the Department of Public International and European Law; Faculty of Law, Administration and Economics; University of Wroclaw; adriana.kalickamikolajczyk@uwr.edu.pl; ORCID: https://orcid.org/0000-0002-1250-5052.

${ }^{1}$ EU relations with the Vatican City State and the Principality of Liechtenstein are not the subjects of this paper.

${ }^{2}$ Policy Department, Structural and Cohesion Policies, The Relationship between European Micro-States and the European Union http://www.europarl.europa.eu/RegData/etudes/note/join/2008/397247/IPOL-

REGI_NT\%282008\%29397247_EN.pdf. 
Their limited relations with the EU can be characterized as an "absorption model"3.

The EU maintains relations with all the Mini-States on the basis of Article 8 of the Treaty on the European Union (TEU) which states that the EU "shall develop a special relationship with neighbouring countries, aiming to establish an area of prosperity and good neighbourliness, founded on the values of the Union and characterised by close and peaceful relations based on cooperation" 4 . According to Declaration No.3 on Article 8 of the TEU, "the Union will take into account the particular situation of small-sized countries which maintain specific relations of proximity with it". Prior to the Lisbon Treaty there were no specific constitutional obligations or requirements to develop a close cooperation with neighbouring countries. Currently, this provision, covers tasks and competences regarding the EU's policy towards its neighbours and provides a new additional legal basis for the cooperation with neighbouring countries. The main objective of such cooperation is the establishment of an area of prosperity and good neighbourliness, characterised by close and peaceful relations based on cooperation. The EU thus has competences to take any political or economic measure to achieve this objective. However, the term "special relationship" can be understood very broadly, which means that the EU may offer its neighbours different levels of "deep and enhanced" cooperation or only cooperation within one specific area ${ }^{5}$. Moreover, the EU may develop its external relations with neighbouring partner countries on the basis of "cooperation", which means that both subjects must agree on such special form of common relations and such cooperation must be "founded on the values of the Union". So, relations with neighbouring countries are based on the EU values identified in Article 2 of the TUE: respect for human dignity, freedom, democracy, equality, the rule of law and respect for human rights, including the rights of persons belonging to minorities.

In December 2010, the Council concluded that EU relations with all Mini-States were "extensive but fragmented" 6 , as there are still obstacles to introduce the free movement of persons, goods and services into and out of the EU. Therefore, the Council called the European Commission for an "analysis of the possibilities and modalities of their possible progressive integration into the internal market". Next, in June 2011 the Council adopted an initial report which invited the European External Action Service and the European Commission to deepen their analysis, including exploring "a possible new institutional framework for relations, taking into account the importance of a coherent approach for all three countries"7.

\footnotetext{
3 S Gsthöl, 'Mapping the European Union's neighbourhood relations. The European Economic Area as a "prototype" for the integration of the EU neighbours' in S Gsthöl, The European Neighbourhood Policy in a Comparative Perspective. Models, challenges and lessons (Routledge 2016) 22.

${ }^{4}$ Consolidated version of the Treaty on European Union [2008] OJ 2012 C326/13.

${ }^{5} \mathrm{P}$ van Elsuwege, R Petrov, 'Article 8 TEU: Towards a New Generation of Agreements with the Neighbouring Countries of the European Union' (2011) 36 EL Rev 692.

${ }^{6}$ Council Conclusions on EU Relations with EFTA countries of 14 December 2010.

7 'EU relations with the Principality of Andorra, the Republic of San Marino and the Principality of Monaco' - Report from the Presidency to the Council, 14 June 2011, Council document 11466/11, point 14 .
} 
All Mini-States have expressed the wish to enhance their relations with the EU, however there are some differences in terms of the extent and material scope of such relations. Monaco has expressed interest to discuss only options for its closer integration into the internal market. Andorra and San Marino have expressed openness to consider a wide range of scenarios for enhanced European integration, ranging from EEA Membership to a multilateral or bilateral Association Agreement with the EU. However, all Mini-States want to safeguard their specificities and identities in their relations with the EU.

The main objective of this paper is to examine the possibilities of future deeper and enhanced cooperation between the EU and Mini-States.

\section{CURRENT LEGAL FOUNDATIONS OF COOPERATION BETWEEN THE EU AND THE MINI-STATES}

Concerning the legal framework of the EU's cooperation with all Mini-States, bilateral trade in goods is governed by Customs Union Agreements. Monaco has concluded such an agreement with France and is part of the customs territory of the EU, whereas San Marino and Andorra both have concluded a Customs Union Agreements with the EU. Furthermore, the EU has Monetary Agreements and Savings Taxation Agreements in place with all of them. In addition, the European Commission has proposed to negotiate Anti-Fraud and Tax Information Exchange Agreements with them ${ }^{8}$. All these international agreements are bilateral agreements that are concluded within the exclusive competences of the EU.

\section{Customs Union Agreements}

The European Economic Community (EEC) has concluded Customs Union Agreements with Andorra and San Marino ${ }^{9}$. The agreement establishes a customs union for mainly industrial products and includes provisions applicable to agricultural products which are not covered by the customs union. The practical result of this is that these two states are treated as a member of the EU for trade in manufactured goods for which no tariffs are applied and as a non-EU member for trade in agricultural products. Monaco is also an integral part of the EU customs territory, however on the basis of a Customs Convention signed with France in 1963 it applies directly most measures related to Value Added Tax and excises duties, in particular those related to the free movement of goods within the EU. The participation in the EU territory does not extend to the area of external trade. Preferential trade agreements apply only to goods originating on the territory of the EU.

\footnotetext{
${ }^{8}$ Commission Communication on 'Concrete ways to reinforce the fight against tax fraud and tax evasion including in relation to third countries', COM(2012)351 final, Brussels, 27 June 2012.

9 'Agreement in the form of an Exchange of Letters between the European Economic Community and the Principality of Andorra' [1990] OJ L 347/14; 'Interim Trade and Customs Union Agreement between the European Economic Community and the Republic of San Marino’ [2002] OJ L 84/43.
} 


\section{Cooperation Agreements}

In November 2004, the EEC signed a Cooperation Agreement with Andorra, which entered into force on the 1 July $2005^{10}$ and in December 1991 with San Marino, which entered into force on the 1 April $2002^{11}$. Both these agreements intended to complement the Customs Union Agreements, and they cover a wide range of issues: environment, communication, information, culture and education, and social issues, transport, energy, regional and crossborder cooperation, information and culture; education, vocational training and youth; social and health issues; trans-European networks and transport; regional policy. The contracting parties may, by mutual consent, extend the areas of cooperation by concluding agreements on specific matters. However, the agreements do not cover the free movement of persons and capital, nor the freedom to provide cross-border services.

\section{Monetary Agreements}

The EU has concluded Monetary Agreements with each of MiniStates, the provisions of which allow them to use the Euro as legal tender and mint Euro coins up to a specified maximum value ${ }^{12}$. In exchange, they have committed to gradually incorporate relevant EU acquis into their internal legislation, covering: Euro banknotes and coins; banking and financial law; prevention of money laundering; fraud and counterfeiting; and the sharing of statistical information ${ }^{13}$. All Mini-States have accepted the exclusive competence of the Court of Justice of the EU for the settlement of any disputes between the parties in relation to these agreements.

\section{Savings Tax Agreements}

The EU has also signed with all Mini-States Agreements on Savings Taxation ${ }^{14}$, which provide for measures equivalent to those laid down in Directive 2003/48/EC on taxation of savings income in the form of interest payments ${ }^{15}$. The main objective of this Directive "[...] is to enable savings income in the form of interest payments made in one Member State to beneficial owners who are individuals resident in another Member State to be made subject to effective taxation in accordance with the laws of the latter

\footnotetext{
${ }^{10}$ [2005] OJ L 135/14.

11 [2002] OJ L 84/43.

12 Monetary Agreement between the European Union and the Principality of Andorra' [2011] OJ C 369/1; 'Monetary Agreement between the European Union and the Principality of Monaco' [2012] OJ C 310/1; 'Monetary Agreement between the European Union and the Republic of San Marino’ [2012] OJ C 121/5.

${ }^{13}$ As set out in the Annex to each Agreement.

14 'Agreement between the European Community and the Principality of Andorra providing for measures equivalent to those laid down in Council Directive 2003/48/EC on the taxation of savings income in the form of interest payments' [2004] OJ L 359/33; 'Agreement between the European Community and the Principality of Monaco providing for measures equivalent to those laid down in Council Directive 2003/48/EC, [2005] OJ L 19/55; 'Agreement between the European Community and the Republic of San Marino providing for measures equivalent to those laid down in Council Directive 2003/48/EC on the taxation of savings income in the form of interest payments. Memorandum of Understanding' [2004] OJ L 381/33.

${ }^{15}$ Council Directive 2003/48/EC of 3 June 2003 on the taxation of savings income in the form of interest payments, [2003] OJ L 157/38.
} 
Member State"16. This means that savings income in the form of interest payments made in these States to beneficial owners who are residents of a Member State have to be subject to a withholding tax levied by paying agents established on their territory. However, its scope is limited to the taxation of savings income in the form of interest payments on debt claims, to the exclusion, inter alia, of the issues relating to the taxation of pension and insurance benefits.

\section{Anti-Fraud and Tax Information Exchange Agreements}

Following a recommendation from the European Commission, the Council in 2010 authorised it to negotiate Anti-Fraud and Tax Information Exchange Agreements with Andorra, Monaco and San Marino ${ }^{17}$, taking into account international developments in this area. The European Commission is envisaging two-pillar agreements, including not only anti-fraud measures but also comprehensive administrative tax cooperation.

\section{Agreement on Pharmaceuticals, Cosmetic Product and Medical Devices}

In December 2003 the European Community concluded an agreement with Monaco regarding the application of the EU legislation to pharmaceuticals, cosmetic products and medical devices ${ }^{18}$. The agreement specifies that the relevant EU legislation applies in Monaco and that the French authorities can monitor the production in Monaco of those products against the particular standards outlined in the EU legislation. However, none of the other EU Member States are similarly obliged to recognise the production of Monaco's goods. The goods produced in Monaco are thus not assimilated to products of the EU origin.

\section{Schengen Agreements}

Andorra is not part of the Schengen area. Border controls are carried out at the borders between Andorra and its neighbours, France and Spain. However, it coordinates its visa requirements with the Schengen area and accepts Schengen visas. According to a pragmatic approach taken by the Member States, at the external borders of the EU Andorran nationals are allowed to undergo passport controls at the counters for citizens of the EU and EFTA Member States. Monaco is not also a Contracting Party to the Schengen Convention. However, by virtue of two bilateral agreements with France ${ }^{19}$, its territory is within the external borders of the Schengen area; consequently, EU and Monaco nationals can travel freely without a visa throughout the whole of the Schengen area, including Monaco. The agreements provide for the necessary security safeguards and the

\footnotetext{
${ }^{16}$ Article 1 of Council Directive 2003/48/EC.

${ }^{17}$ Economic and Financial Affairs Council of 19 January 2010 (Council document 5400/10). 18 [2003] OJ L 332/41.

19 Two agreements in the form of exchanges of letters between Monaco and France, signed the 15 December 1997, adapted the section of the Convention on Good Neighbourly Relations of 18 May 1963 on the entry, stay and establishment of foreigners in Monaco to the provisions of the Convention on the Implementation of the Schengen Agreement.
} 
establishment of controls at Monaco's external borders, which are carried out by the French authorities. San Marino is also not part of the Schengen area, but there are no border controls between Italy and San Marino. San Marino is not associated to the implementation of other elements of the Schengen acquis, such as police and judicial cooperation.

Nevertheless, citizens of all Mini-States can enter and travel through the EU without a visa. Indeed, on the basis of Council Regulation 539/2001, nationals of the Mini-States may enter, transit through, and travel freely within the Schengen area for a period of up to three months within any six month period without a visa ${ }^{20}$.

\section{POSSIBLE SCENARIOS FOR FUTURE CLOSER AND ENHANCED INTEGRATION WITH THE EU}

All of the Mini-States located in Europe maintain close relations with the EU and have very close ties with their neighbours. However, closer and enhanced integration with the EU will ensure the greatest possible freedom of movement of citizens, freedom of establishment will support economic growth, employment and job creation and finally will strengthen the legal framework against illegal financial activities between Mini-States and the EU.

Below there are presented four possible scenarios for future closer and enhanced cooperation between the EU and all Mini-States ${ }^{21}$.

\section{Option One: A Sectoral Approach}

This option would consist of negotiating sectoral agreements for access to parts of the internal market, such as in the area of the free movement of persons or services. To achieve full integration of all Mini-States, separate agreements could be concluded with each country on different policy areas, such as: free movement of persons; freedom of establishment and free movement of services; customs union and free movement of goods; flanking measures, horizontal policies and other areas of cooperation. These agreements would need to be complemented by provisions on shared values and institutions to underpin the relationship and ensure the smooth functioning of the agreements. This approach would therefore require negotiation and the conclusion of up to 20 separate agreements with all these countries. This approach might allow the tailoring of the provisions of the agreements to each country's specific needs and could offer some flexibility. However, there are two essential drawbacks to this approach. Firstly, it is not in the EU's interest to negotiate and conclude such a large number of agreements, as the negotiating effort required would be multiplied in comparison with a single agreement. Second, an approach based on sectoral

\footnotetext{
${ }^{20}$ Council Regulation (EC) No 539/2001 of 15 March 2001 listing the third countries whose nationals must be in possession of visas when crossing the external borders and those whose nationals are exempt from that requirement, [2001] OJ L 81/1.

${ }^{21}$ Communication from the Commission to the European Parliament, the Council, the European Economic and Social Committee and the Committee of Regions, 'EU Relations with the Principality of Andorra, the Principality of Monaco and the Republic of San Marino' $\operatorname{COM}(2012) 680$ final, 15-18.
} 
agreements to meet the most pressing concerns of the Mini-States would not provide comprehensive solutions to the problems they face. Moreover, if each Mini-States opted for market access in different policy areas, it would result in different arrangements for each country, leading to an incoherent web of unconnected agreements that would be difficult to manage ${ }^{22}$.

\section{Option Two: Participation in the European Economic Area}

The EEA Agreement was signed in Oporto on 2 May 1992, and came into force on 1 January $1994^{23}$. It was concluded between the European Community and its Member States, on the one hand, and the EFTA countries, except for Switzerland, on the other. Today only Iceland, Norway and Liechtenstein are the EU's associated partners. The core of the EEA Agreement provides for the application of the EU Treaties and secondary legislation relating to the four freedoms but also provides for the cooperation in all EU's horizontal and flanking policies: consumer protection, company law, environment, social policy, statistics, research and technological development, education, training and youth, employment, tourism, culture, civil protection, enterprise, entrepreneurship and small and medium-sized enterprises.

According Article 1, the main objective of the EEA Agreement " [...] is to promote a continuous and balanced strengthening of trade and economic relations between the Contracting Parties with equal conditions of competition, and the respect of the same rules, with a view to creating a homogeneous European Economic Area". In order to attain the objectives, the cooperation between the Parties covers: free movement of goods; free movement of persons; free movement of services; free movement of capital; the setting up of a system ensuring that competition is not distorted and that the rules thereon are equally respected; but also cooperation in other fields, such as research and development, the environment, education and social policy $^{24}$. However, the EEA Agreement does not cover: common agriculture and fisheries policies; customs union; common trade policy; common foreign and security policy; justice and home affairs; direct and indirect taxation and economic and monetary union. So, the EEA Agreement creates a free trade area between the EU and the EFTA States. In order to ensure a homogeneous application of the relevant provisions, the EEA Agreement has established a parallel system of supervision and dispute settlement, with "quasisupranational" features. The powers are exercised, on the EU side, by the European Commission and the Court of Justice of the EU ${ }^{25}$ and on the EFTA States, by the EFTA Surveillance Authority and the EFTA Court ${ }^{26}$. During

\footnotetext{
${ }^{22}$ Communication from the Commission to the European Parliament, the Council, the European Economic and Social Committee and the Committee of Regions, 'EU Relations with the Principality of Andorra, the Principality of Monaco and the Republic of San Marino' $\operatorname{COM}(2012) 680$ final 15-16.

${ }^{23}$ Agreement on the European Economic Area [1994] OJ L 1/3.

${ }^{24}$ Article 1 (2) of the EEA Agreement.

${ }^{25}$ Article 109 of the EEA Agreement.

${ }^{26}$ Articles 32 and 34 of the EEA Agreement.
} 
2010-2013 comprehensive reviews of the EEA Agreement took place ${ }^{27}$. The European Commission, suggested: to extend the material scope and add judicial cooperation to the EEA Agreement; to explore the possibility of simplifying the procedures with regard to the technical functioning of it and finally, to open up to more members, such as Mini-States ${ }^{28}$.

To sum up, the EEA Agreement was concluded between two trade and economic areas- the EU and the EFTA, so that it would be necessary for the Mini-States to become a member of either one in order to join the EEA ${ }^{29}$. The EU would need to discuss with the EFTA Members States, the possibility of its enlarging to include the Mini-States. However, the EFTA Member States are very sceptical about this idea because the economies of all three MiniStates are not sufficiently diversified ${ }^{30}$.

\section{Option Three: Association Agreement}

Association Agreements play a fundamental role in the EU's external policy, because they simplify access to the EU internal market for goods from third countries and, at the same time, commit the EU to cooperate with them economically and financially.

Article 217 TFUE provides a legal basis for the EU to, "conclude with one or more third countries or international organisations agreements establishing an association involving reciprocal rights and obligations, common action and special procedure". As we can see, Article 217 does not define the association and does not give particulars of possible contents of an association agreement. Advocate-General Mayras in the Hageman Case said that an association agreement may lead to the establishment of very close institutional cooperation between the Parties without going as far as the unconditional accession of that country ${ }^{31}$. The content of such treaty is not specially defined in the Union Treaties. However, as the Court of Justice has held, "an association agreement creates special, privileged links with a third country which must, at least to a certain extent, take part in the Union system" 32 . So, the EU has the power to "guarantee commitments towards nonmember countries in all fields covered by the Treaties" 33 , however "reciprocal rights and obligations" does not mean equality of contractual obligations ${ }^{34}$. It is sufficient that the agreement takes account of the reciprocal economic interests of both contracting parties in general. Each association agreement constitutes a framework for long-term cooperation and sets up joint bodies, composed, on the one hand, of members of the national governments or

\footnotetext{
${ }^{27}$ Commission Staff Working Document 'A review of the functioning of the European Economic Area' SWD(2012) 425 final; European Economic Area, Consultative Committee, Resolution and Report on the EEA Review, http://www.efta.int/media/documents/advisorybodies/consultative-committee/cc-resolutions/English/2012-05-04-eea-cc-resolution-onthe-eea-review.pdf (accessed 15.4.2017).

${ }^{28}$ Commission Staff Working Document.

${ }^{29}$ Article 128 of the EEA Agreement.

${ }^{30} \mathrm{G}$ Støre, 'Biannual address to the Storting on important EU and EEA matters' Oslo, 19 May 2011, https://www.regjeringen.no/en/aktuelt/biannual_170418/id2549368/ (accessed 15.4.2017)

${ }^{31}$ Case 181/73 R \& V Haegeman v Belgian State, [1974] ECR para 41.

${ }^{32}$ Case 12/86 Meryem Demirel v Stadt Schwäbisch Gmünd, [1987] ECR paras. 9-11.

${ }^{33}$ Case 12/86 (n 32) para. 9.

${ }^{34}$ Case 87/75 Conceria Daniele Bresciani v Amministrazione Italiana delle Finanze, [1976] ECR para. 22.
} 
members of the Council, and on the other, of members of the government of each third country, which generally takes its decisions unanimously. From the date of entry into force they are binding upon the EU institutions and on its Member States, its provisions form an integral part of the EU law and finally, in certain circumstances they may have direct effect ${ }^{35}$.

To sum up, an Association Agreement includes four key elements which allow it to be distinguished from other international agreements concluded by the EU: implies a close relations between the parties, extending to a participation of an associated country in certain objectives of the EU Treaties; goes beyond commercial issues and may cover a number of areas of the EUs activity; the institutional system of such an agreement is very developed with the decision- making power; the links between the parties are permanent in nature, which is why these type of agreements are generally concluded for indefinite periods ${ }^{36}$.

That is why an Association Agreement could offer the Mini-States a high degree of integration, including partial or full access to the EU's internal market, its flanking measures and horizontal policies. It could also provide for participation in other areas of EU activity. The Association Agreement would set out the underlying values, principles and institutional foundations of the relationship. The Agreement could be a single multilateral agreement between the EU and the three Mini-States, possibly following the European Economic Area model. The conclusion of a bilateral treaty with each MiniState would theoretically be possible but not desirable due to the added complexity and the tendency for unnecessary differentiation ${ }^{37}$. This option would offer the additional advantage to the three Mini-States of regulating their mutual relations. In any case, for an Association Agreement to be viable, a satisfactory solution would have to be found to ensure that the relevant parts of the acquis are made applicable in those countries, that the acquis is actually implemented and enforced by the Mini-States or authorities entrusted by them with that task, and that the application of the acquis is monitored and, as the case may be, enforced vis-à-vis those countries ${ }^{38}$.

\section{Option Four: Neighbourhood Agreement}

On the base of Article 8(2) TEU "[...] the Union may conclude specific agreements with the countries concerned. These agreements may contain reciprocal rights and obligations as well as the possibility of undertaking activities jointly. Their implementation shall be the subject of periodic consultation”. So, the area of prosperity and good neighbourliness

\footnotetext{
${ }^{35}$ Case 181/73, paras. 4-6, Case 12/86, para 7, Case 30/88 Hellenic Republic v Commission of the European Communities [1989] ECR para 12.

${ }^{36}$ I MacLeod, ID Hendry, S Hyett, The External Relations of the European Communities (1996) 370 .

37 Communication from the Commission to the European Parliament, the Council, the European Economic and Social Committee and the Committee of Regions, 16-17.

38 The important role of monitoring and enforcement of the acquis in those countries could be assumed by the Commission and the Court of Justice of the European Union; the EEA EFTA institutions (EFTA Surveillance Authority and EFTA Court); or an equivalent supranational authority. The options would need to be discussed and the preferred option agreed with the small-sized countries.
} 
with neighbouring countries can be achieved by "specific agreements, which may contain reciprocal rights and obligations as well as the possibility of undertaking activities jointly".

This means, that since the Lisbon Treaty, the EU has a new, express and specific legal foundation to conclude neighbourhood agreements, the scope of which may cover all the EU's policies. They are modelled upon the provisions of Article 217 TFEU. However, there are three main differences between these two types of international agreements: they may contain reciprocal rights and obligations, which does not necessarily mean equal rights and obligations; they do not provide "special procedures", which mean that the neighbouring country is excluded from the participation in the EU institutional system ${ }^{39}$; and finally, they provide an obligation to monitor their implementation by means of "periodic consultation", which mean that such an agreement will be only a subject of common and frequent inspection made by both Parties, and not by a judicial institution ${ }^{40}$.

To sum up, the EU and neighbouring partner countries have a lot of flexibility in deciding what level of cooperation to choose, they may choose an association agreement or a neighbourhood agreement. However, one more thing should be stressed, the Article 8 is placed in the first part of the TEU, which means that provisions of the Article 8 (2) may be seen as the specific legal basis - lex specialis to provisions of the Article 217 TFUE for concluding Association Agreements with neighbouring countries.

\section{CONCLUSIONS}

Andorra, Monaco and San Marino are independent states of small territorial size; however, they enjoy good relations with the EU through bilateral agreements. Andorra and San Marino have a customs union with the EU, while Monaco has a customs union with France. Their customs unions agreements facilitate, to a certain extent, bilateral trade in goods with the EU, but these countries still face market access obstacles in the form of technical barriers to trade, such as the EU's rules in the areas of consumer protection and product safety. Financial services and tourism are key areas for all three countries. In any event, there would be mutual benefits from closer economic integration between the Mini-States and the EU. There is a clear economic interest on the side of all three Mini-States to enhance their relations with the EU. Currently, businesses from these countries face obstacles when wishing to provide services in the EU, as their existing agreements with the EU do not provide for the free movement of services or of establishment.

During the first half of 2011, all of these Mini-States expressed their wish to further develop relations with the EU. Concerning the future, two options could be considered: option three: association agreement and option four: participation in the EEA; however, it seems that this strategic decision has been made, because on 16 December 2014 the Council adopted a decision authorising the opening of negotiations on one or several association

\footnotetext{
${ }^{39}$ Communication (n 37) 12.

${ }^{40}$ D Hanf, 'The European Neighbourhood Policy in the Light of the New: Neighbourhood Clause (Article 8 TEU)' in E Lannon The European Neighbourhood Policy's Challenges (Lang 2012) 111
} 
agreements between the EU and Andorra, Monaco and San Marino and on 15 March 2015 the negotiation process was launched.

\section{References}

Elsuwege P van, Petrov R, 'Article 8 TEU: Towards a New Generation of Agreements with the Neighbouring Countries of the European Union' (2011) 36 EL Rev.

Gsthöl S, 'Mapping the European Union's neighbourhood relations. The European Economic Area as a "prototype" for the integration of the EU neighbours' in S Gsthöl The European Neighbourhood Policy in a Comparative Perspective. Models, challenges and lessons (Routledge 2016).

Hanf D, 'The European Neighbourhood Policy in the Light of the New: Neighbourhood Clause (Article 8 TEU)' in E Lannon, The European Neighbourhood Policy's Challenges (Lang 2012).

MacLeod I, Hendry ID, Hyett S, The External Relations of the European Communities (1996).

Støre G, 'Biannual address to the Storting on important EU and EEA matters' Oslo, 19 May 2011, https://www.regjeringen.no/en/aktuelt/biannual_170418/id2549368/ (accessed 15.4.2017). 